\title{
POTENTIAL PROTECTIVE ROLE OF SELENIUM IN EXPERIMENTAL SUBACUTE INTOXICATION WITH ETHEPHON IN RATS
}

\author{
MIHAI TUDOR ${ }^{1}$, BOGDAN GABRIEL ȘLENCU ${ }^{1}$, RODICA CUCIUREANU ${ }^{1}$, MAGDALENA \\ CUCIUREANU $^{2 *}$, NINA FILIP $^{2}$, CRISTIANA FILIP ${ }^{2}$, CARMEN SOLCAN $^{3}$ \\ ${ }^{I}$ Faculty of Pharmacy, "Grigore T. Popa” University of Medicine and Pharmacy Iași, 16 Universităţii Street, 700115, Iași, \\ Romania \\ ${ }^{2}$ Faculty of Medicine, "Grigore T. Popa” University of Medicine and Pharmacy Iași, 16 Universităţii Street, 700115, Iași, \\ Romania \\ ${ }^{3}$ Faculty of Veterinary Medicine, "Ion Ionescu de la Brad” University of Agricultural Sciences and Veterinary Medicine Iași, \\ 3 Mihail Sadoveanu Alley, 700490, Iaşi, Romania
}

*corresponding author: mag.cuciureanu@umfiasi.ro

Manuscript received: November 2017

\begin{abstract}
Ethephon (2-chloroethylphosphonic acid) is a widely used plant growth regulator. This study aims to evaluate the potential protective effect of sodium selenite (Se) in ethephon-induced subacute intoxication. We worked on 4 groups of Wistar rats which received as follows: control group - saline; group Se - selenium $1 \mathrm{mg} / \mathrm{kg} / \mathrm{day}$; group Eth - ethephon $200 \mathrm{mg} / \mathrm{kg} / \mathrm{day}$; $\mathrm{Se}+$ Eth - selenium $1 \mathrm{mg} / \mathrm{kg} / \mathrm{day}$ and ethephon $200 \mathrm{mg} / \mathrm{kg} /$ day. The activity of glutathione peroxidase (GPx), alkaline phosphatase, superoxide dismutase (SOD), total antioxidant status (TAS), alanine aminotransferase (ALT), aspartat aminotransferase (AST), creatinine and urea have been determined in plasma for all groups of rats. Se administration (in group $\mathrm{Se}+\mathrm{Eth})$ reversed the elevation of ALT $(44.68 \pm 8.73 \mathrm{U} / \mathrm{L}$ versus $55.77 \pm 4.87 \mathrm{U} / \mathrm{L}, \mathrm{p}=0.0406)$, urea $(218.33 \pm 41.67 \mathrm{mg} / \mathrm{dL}$ versus $270 \pm 36.33 \mathrm{mg} / \mathrm{dL}, \mathrm{p}=0.0369)$ and antagonised the decrease of TAS activity $(3.30 \pm 0.17 \mathrm{mmol} / \mathrm{L}$ versus $2.69 \pm 0.45$ $\mathrm{mmol} / \mathrm{L}, \mathrm{p}=0.0088$ ) versus group Eth. Selenium (group Se+Eth) alleviated the histopathological aspect compared to group Eth. In conclusion, Selenium showed a partial protective effect in ethephon-induced subacute intoxication in rats.
\end{abstract}

\section{Rezumat}

Etefonul (acid 2-cloroetilfosfonic) este unul dintre cei mai utilizaţi reglatori de creştere pentru plante. Scopul acestui studiu a fost de a evalua efectul selenitului de sodiu (Se) în intoxicaţia experimentală subacută cu etefon. Şobolanii masculi rasa Wistar au fost repartizaţi în 4 loturi, care au primit astfel: control - ser fiziologic; Se - seleniu $1 \mathrm{mg} / \mathrm{kg} / \mathrm{zi}$; Eth - etefon $200 \mathrm{mg} / \mathrm{kg} / \mathrm{zi}$; Se+Eth - seleniu $1 \mathrm{mg} / \mathrm{kg} / \mathrm{zi}$ și etefon $200 \mathrm{mg} / \mathrm{kg} / \mathrm{zi}$. S-a determinat nivelul plasmatic al glutation peroxidazei (GPx), fosfatazei alcaline, superoxid dismutazei (SOD), statusului total antioxidant (TAS), alaninaminotransferazei (TGP), aspartataminotransferazei (TGO), creatininei şi ureei şi s-a realizat examenul histopatologic hepatic. Administrarea seleniului (lotul Se+Eth) a determinat scăderea nivelului TGP $(44,68 \pm 8,73 \mathrm{U} / \mathrm{L}$ versus $55,77 \pm 4,87 \mathrm{U} / \mathrm{L}, \mathrm{p}=0,0406)$, ureei $(218,33 \pm 41,67 \mathrm{mg} / \mathrm{dL}$ versus $270 \pm 36,33 \mathrm{mg} / \mathrm{dL}, \mathrm{p}=0,0369)$, creşterea nivelului TAS $(3,30 \pm 0,17 \mathrm{mmol} / \mathrm{L}$ versus $2,69 \pm 0,45 \mathrm{mmol} / \mathrm{L}, \mathrm{p}=0,0088)$ şi ameliorarea aspectului histopatologic comparativ cu lotul Eth. În concluzie, seleniul prezintă un efect parţial protector în intoxicaţia subacută cu etefon la şobolani.

Keywords: ethephon, intoxication, plant growth regulator, selenium, rat animal model

\section{Introduction}

Ethephon (2-chloroethylphosphonic acid) is a widely used plant growth regulator, with a wide action spectrum [1]. Ethephon can be used in agriculture for hurrying up flower formation or for ripening or colouring of fruits $[1,14]$. Ethephon also shortens and hardens the straw of cereals, thus increasing their mechanical resistance [4]. It is also used for post-harvest acceleration of ripening, in case of mango fruits and bananas [9].

Ethephon is usually formulated as solutions (20 $720 \mathrm{~g} / \mathrm{L}$ ) and is marketed under various brands, corresponding to specific uses. Formulations containing ethephon are registered in more than 60 countries [6,
12]. Ethephon is currently banned in many countries, including Romania. Its action as a growth stimulator is based on the rapid absorption by the plant and the release of its main metabolite ethene, a natural hormone for plants [18].

Ethephon can be present as residues in food products to which treatments were applied, either before harvest or post-harvest. For cereals, the residue limit is 0.5 $\mathrm{mg} / \mathrm{kg}$ in Japan and China and $0.05 \mathrm{mg} / \mathrm{kg}$ in the European Union [5, 20].

The median lethal dose (LD50) for rats, in case of oral administration, is between 3400 and $4229 \mathrm{mg} / \mathrm{kg}$ body weight [15]. In case of oral administration to rodents, ethephon causes gastroenteritis, respiratory and renal pathologies, cardiac fibrosis and necrotic 
FARMACIA, 2018, Vol. 66, 3

hepatitis. Ethephon is also teratogenic [9, 17]. It has also been reported that ethephon exerts cholinergic effects on intestinal muscles [23].

The report created during the Joint FAO/WHO meeting on pesticide residues (JMPR) in 2016 concluded that it is unlikely that the long term intake of ethephon residues that result from its rational and approved uses in agriculture could constitute a concern for public health [13].

Selenium is an essential microelement that enters in the structure of many proteins and has specific functions in the active site of selenium-dependent enzymes which are named selenoproteins $[12,19]$. Administration of selenium in doses higher than those necessary for covering the physiological requirement has proven to be beneficial in case of some pathologic conditions, including exposure to some toxic substances ingested together with the food products. There is published data concerning the role of different agents in experimental intoxications with acrylamide [22], with toxic metals $[2,16]$ or with other substances used in agriculture $[11,21]$.

This study aimed to evaluate the potential protective effect of sodium selenite in ethephon-induced subacute intoxication in rats.

\section{Materials and Methods}

\section{Reagents}

Sodium selenite (CAS 10102-18-8; purity min. 99\%) and ethephon (CAS 16672-87-0; purity 98,6\%) were purchased from Sigma Aldrich. All other reagents used were of analytical grade.

Laboratory animals and procedures

Adult Wistar male rats $(\mathrm{n}=24)$ having the weight ranging 180 - $230 \mathrm{~g}$ were obtained from Laboratory Animal Center of Cantacuzino Institute of Research, Bucharest, Romania. They were placed in plexiglas cages with the floor covered with sawdust. The rats were exposed to a controlled environment with $12 \mathrm{~h}$ light/dark cycle and a temperature of $18-25^{\circ} \mathrm{C}$ before and throughout the experimental period. The animals had free access to food (standard lab rat chow) except 6 hours before the experiment but tap water ad libitum. These experiments were approved by the University's Committee for Bioethics and animal experimentation according to the 86/609/EEC directive. After a habituation period of one week, the rats were randomly divided into four groups of $6 \mathrm{Wistar}$ male rats each, in order to receive different treatments (by gavage). The control group was treated with saline, group Se received selenium $1 \mathrm{mg} / \mathrm{kg} /$ day for 14 days, group Eth - ethephon $200 \mathrm{mg} / \mathrm{kg} /$ day for 14 days, group Se+Eth - ethephon selenium $1 \mathrm{mg} / \mathrm{kg} /$ day and $200 \mathrm{mg} / \mathrm{kg}$ /day for 14 days.

One day after the last administration, all animals were weighed again, than it was administered ketamine
$100 \mathrm{mg} / \mathrm{kg}$ i.p. and blood samples were collected by cardiac puncture.

The activity of glutathione peroxidase (GPx), alkaline phosphatase, superoxide dismutase (SOD), total antioxidant status (TAS), alanine aminotransferase (ALT), aspartat aminotransferase (AST), creatinine and urea have been determined in plasma for all groups.

For the pathological examination, the hepatic fragments were formalin fixed, embedded in paraffin and stained with haematoxylin-eosin. The histopathological lesions were evaluated without any information regarding the chemicals administrated during the experiment. The stained sections were analysed and photographed by using an Olympus CX41 microscope with an integrated DP21 digital camera (Olympus Corporation, Japan). The hepatic architecture was evaluated by randomly examining 10 various fields of view per tissue section and noted as 1 (normal), 2 (partially preserved) and 3 (modified).

Statistical analysis

Results were expressed as means \pm standard deviation of three replicates. The statistical analysis was performed using analysis of variance (ANOVA) one way. Tukey test was used for multiple comparisons (software Stats Direct version 3). A value of $p<0.05$ was considered significant.

\section{Results and Discussion}

The ethephon administration caused a statistically significant increase of creatinine $(0.65 \pm 0.06 \mathrm{mg} / \mathrm{dL}$ versus $0.53 \pm 0.03 \mathrm{mg} / \mathrm{dL}, \mathrm{p}=0.0017$ ) (Figure 1 ), urea $(270 \pm 36.33 \mathrm{mg} / \mathrm{dL}$ versus $129.16 \pm 16.85 \mathrm{mg} / \mathrm{dL}$, $\mathrm{p}<0.0001)$ (Figure 2), AST $(103.51 \pm 9.69 \mathrm{U} / \mathrm{L}$ versus $70.81 \pm 14.88 \mathrm{U} / \mathrm{L}, \mathrm{p}=0.0089)$ (Figure 3 ), $\operatorname{ALT}(55.77 \pm 4.87 \mathrm{U} / \mathrm{L}$ versus $36.66 \pm 7.77 \mathrm{U} / \mathrm{L}$, $\mathrm{p}=0.0004$ ) (Figure 4) and alkaline phosphatase $(241.02 \pm 17.2 \mathrm{U} / \mathrm{L}$ versus $109.39 \pm 26.09 \mathrm{U} / \mathrm{L}, \mathrm{p}<$ 0.0001 ) (Figure 5) compared to the control group. Group Eth presented decreased levels of TAS (2.69 \pm $0.45 \mathrm{mmol} / \mathrm{L}$ versus $3.4 \pm 0.32 \mathrm{mmol} / \mathrm{L}, \mathrm{p}=0025)$ (Figure 6) and GPx (1291.42 $\pm 68.5 \mathrm{U} / \mathrm{L}$ versus $1749.81 \pm 229.73 \mathrm{U} / \mathrm{L}, \mathrm{p}=0.0008$ ) (Figure 7) compared to the control group.

There were no statistically significant differences between the control group and group $\mathrm{Se}$ in all studied parameters.

Selenium administration (in group $\mathrm{Se}+\mathrm{Eth}$ ) reversed the elevation of ALT $(44.68 \pm 8.73 \mathrm{U} / \mathrm{L}$ versus $55.77 \pm 4.87 \mathrm{U} / \mathrm{L}, \mathrm{p}=0.0406$ ) (Figure 4), creatinine $(0.50 \pm 0.03 \mathrm{mg} / \mathrm{dL}$ versus $0.65 \pm 0.06 \mathrm{mg} / \mathrm{dL}, \mathrm{p}=$ $0.0003)$ (Figure 1), urea $(218.33 \pm 41.67 \mathrm{mg} / \mathrm{dL}$ versus $270 \pm 36.33 \mathrm{mg} / \mathrm{dl}, \mathrm{p}=0.0369)$ (Figure 2), alkaline phosphatase $(181.37 \pm 12.12 \mathrm{U} / \mathrm{L}$ versus $241.02 \pm 17.2 \mathrm{U} / \mathrm{L}, \mathrm{p}=0.0005$ ) (Figure 5) versus group Eth. Selenium treatment in group $\mathrm{Se}+\mathrm{Eth}$ antagonised the decrease of GPx (1676.23 \pm 120.83 $\mathrm{U} / \mathrm{L}$ versus $1291.42 \pm 68.57 \mathrm{U} / \mathrm{L}, \mathrm{p}=0.0043$ ) 
FARMACIA, 2018, Vol. 66, 3

(Figure 7) and TAS activity $(3.30 \pm 0.17 \mathrm{mmol} / \mathrm{L}$ versus $2.69 \pm 0.45 \mathrm{mmol} / \mathrm{L}, \mathrm{p}=0.0088$ ) (Figure 6) found in group Eth. Concerning SOD plasma levels, there was no significant difference between group $\mathrm{Se}+$ Eth and Eth.

Histopathologically, group Eth displayed modified lobular histoarchitecture (score $2.9 \pm 0.12$ ) while group $\mathrm{Se}+\mathrm{Eth}$ partially preserved the lobular histoarchitecture (score $2.2 \pm 0.14, \mathrm{p}<0.0001$ ) (Figure 8). Both the control group and group Se presented normal lobular histoarchitecture (score 1) and no cellular changes.

Assessment of the cellular changes showed that group Eth presented hepatocytes with nuclear alterations specific for cellular death, such as pyknosis, karyorrhexis, cariolisis. Small areas of necrosis around the portobiliary space and in the intralobular

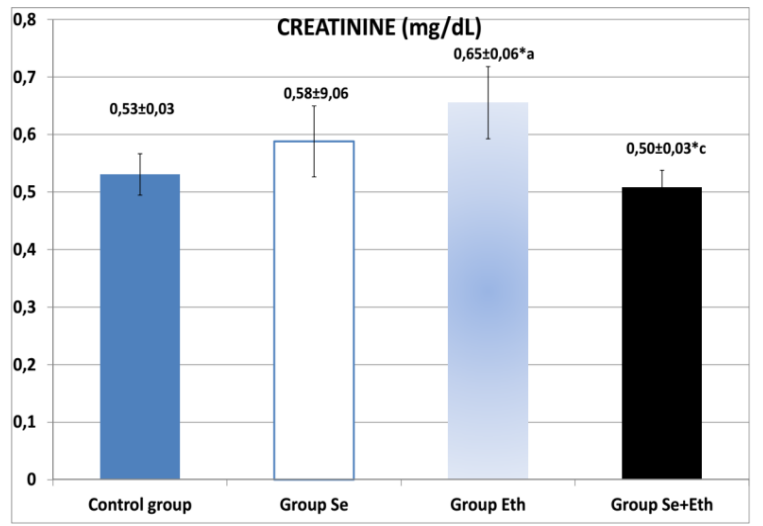

Figure 1.

Creatinine levels

( ${ }^{*} \mathrm{a}-\mathrm{p}<0.05$ compared to control group; *b $-\mathrm{p}<0.05$ compared to Se group; *c $-\mathrm{p}<0.05$ compared to $\mathrm{Se}+$ Eth group)

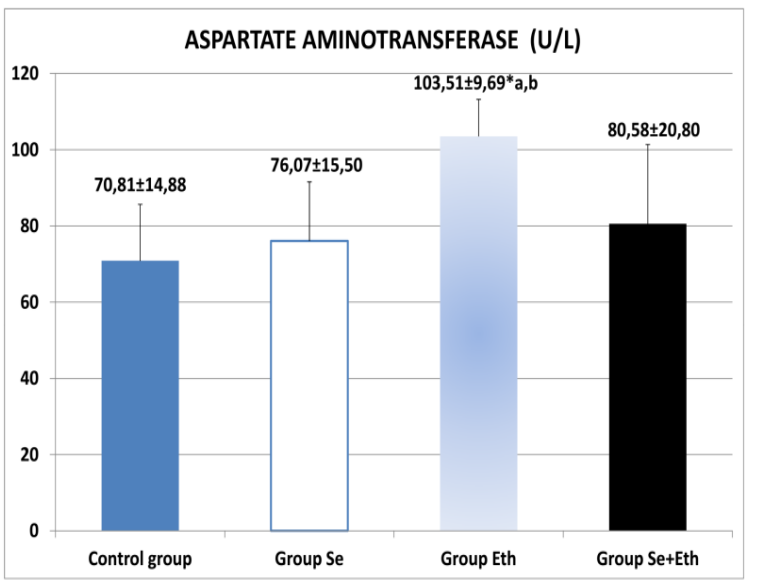

Figure 3.

Aspartate aminotransferase (AST) levels ( $* \mathrm{a}-\mathrm{p}<0.05$ compared to control group; ${ }^{*} \mathrm{~b}-\mathrm{p}<0.05$ compared to Se group) area and ectasiated venules along with sinusoidal capillaries were also noted (Figure 9).

Group Se+Eth presented normal porto-biliary spaces, rare extasiated venules and hepatocytes with large, binucleolated nuclei (Figure 10).

Even though there are many published studies concerning the toxicity of plant growth regulators like ethephon, most of these studies were focused on cholinesterase activity and biochemical changes. There are scarce reports describing the effects induced by ethephon in the target organs during intoxication [23]. Our data are concordance with Bhadoria's study [3] which showed that ethephon exhibits a hepatotoxic effect in rats; both experiments revealed significant increases in ALT, AST, urea and creatinine levels, inflammatory processes and degenerative modifications of the liver tissue that suggest toxic hepatitis.

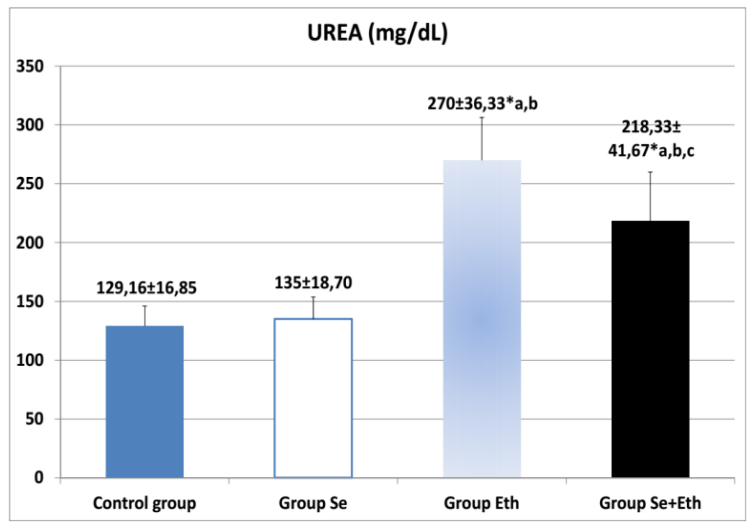

Figure 2.

Urea levels

( $\mathrm{a} a-\mathrm{p}<0.05$ compared to control group; *b $-\mathrm{p}<0.05$ compared to Se group; ${ }^{*} \mathrm{c}-\mathrm{p}<0.05$ compared to $\mathrm{Se}+$ Eth group)

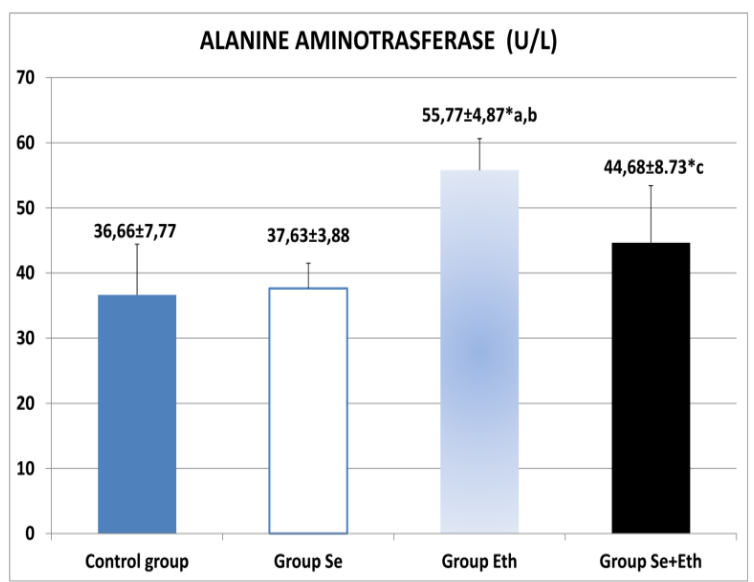

Figure 4.

Alanine transaminase (ALT) levels

(*a - $\mathrm{p}<0.05$ compared to control group; $* \mathrm{~b}-\mathrm{p}<0.05$ compared to Se group; *c $-\mathrm{p}<0.05$ compared to $\mathrm{Se}+$ Eth group) 


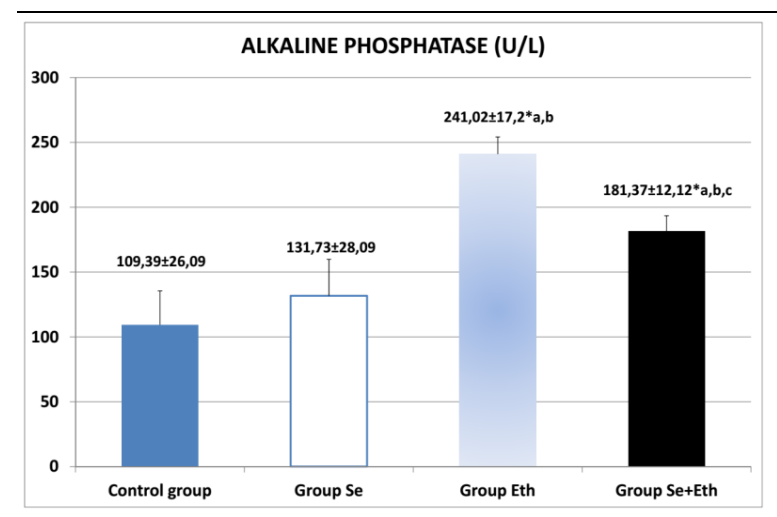

Figure 5.

Alkaline phosphatase level

( $* \mathrm{a}-\mathrm{p}<0.05$ compared to control group; *b - $\mathrm{p}<0.05$ compared to Se group; ${ }^{*} \mathrm{c}-\mathrm{p}<0.05$ compared to $\mathrm{Se}+\mathrm{Eth}$ group)

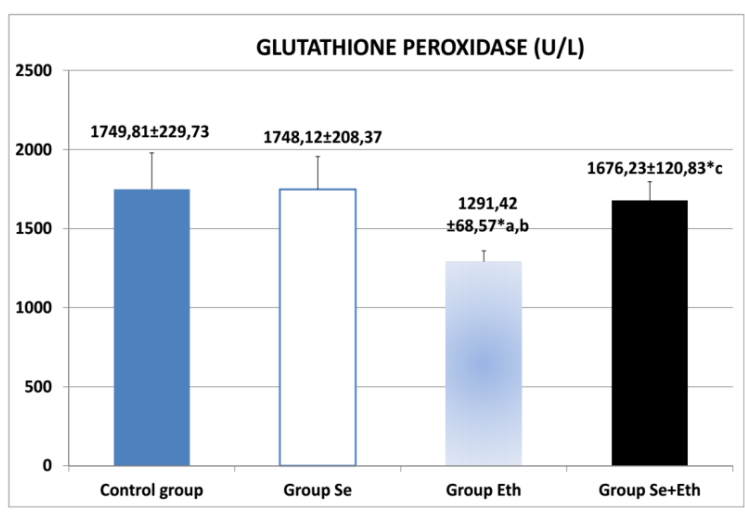

Figure 7.

Glutathione peroxidase levels

( $* \mathrm{a}-\mathrm{p}<0.05$ compared to control group; *b $-\mathrm{p}<0.05$ compared to Se group; ${ }^{*} \mathrm{c}-\mathrm{p}<0.05$ compared to $\mathrm{Se}+\mathrm{Eth}$ group)
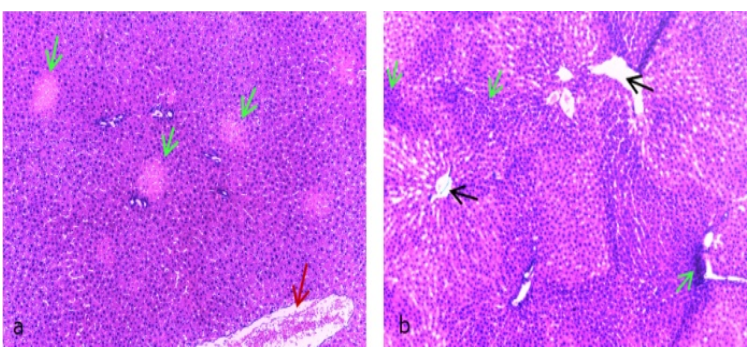

Figure 9.

Hepatic samples of rats from the group Eth (HE staining; $x 40$ )

Goldental-Cohen et al [8] indicated that many genes involved in oxidative stress were induced by ethephon treatment and addition of antioxidants could be beneficial. Our results confirmed that Se alleviated both ethephon-induced biochemical modifications and the histopathological aspect. The presence of binucleate hepatocytes in group $\mathrm{Se}+$ Eth represents a stage of chromosomal hyperplasia, which occurs during the process of cellular regeneration.

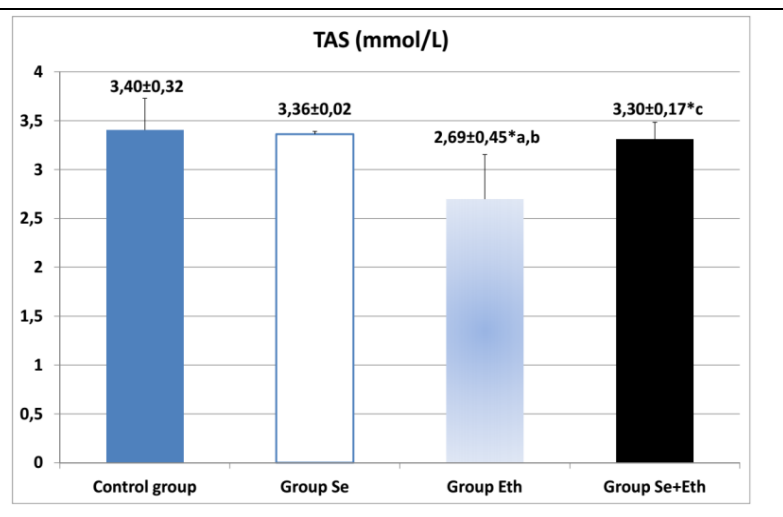

Figure 6.

Total antioxidant status (TAS) levels

(*a - $\mathrm{p}<0.05$ compared to control group; $* \mathrm{~b}-\mathrm{p}<0.05$ compared to Se group; ${ }^{*} \mathrm{c}-\mathrm{p}<0.05$ compared to Se+Eth group)

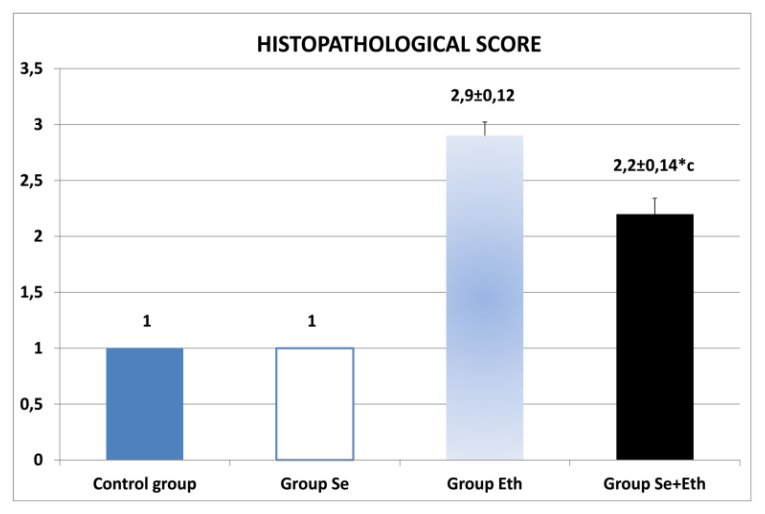

Figure 8.

Histopathological score

$\left({ }^{*} \mathrm{c}-\mathrm{p}<0.05\right.$ compared to Se+Eth group)
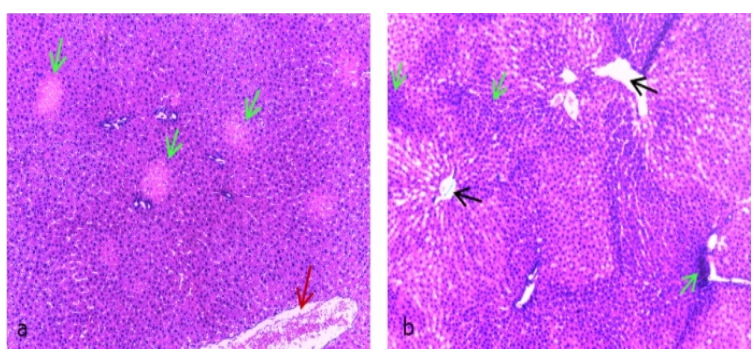

Figure 10.

Hepatic samples of rats from the group Se+Eth (HE staining; $\mathrm{x} 40$ )

\section{Conclusions}

Exposure of rats to ethephon, administered orally in a dose of $200 \mathrm{mg} / \mathrm{kg}$ body weight, resulted in hepatotoxic effects, manifested through significant modifications in the histological structure of the liver. The attenuation of hepatic histological lesions, in the case of the animals that received ethephon coadministered with selenium ( $1 \mathrm{mg} / \mathrm{kg}$ body weight), suggested that selenium may have a partial protective effect in the ethephon - induced subacute intoxication in rats. 


\section{References}

1. Abdelgadir HA, Jager AK, Johnson SD, Influence of plant growth regulators on flowering, fruiting, seed oil content, and oil quality of Jatropha curcas. S Afr J Bot., 2010; 76: 440-446.

2. Al-Fartosi KG, Effect of selenium and lead on some blood parameters of male mice. J Dohuk Univ., 2008; 11: 62-66.

3. Bhadoria P, Nagar M, Bahrioke V, Bhadoria AS, Effect of ethephon on the liver in albino rats: a histomorphometric study. Biomed J., 2015; 38: 421427.

4. Byers RE, Costa G, Vizzotto G, Flower and fruit thinning of peach and other Prunus. Hortic Rev., 2003; 28: 351-392.

5. Dong J, Ma Y, Liu F, Jiang N, Jian Q, Dissipation and residue of ethephon in maize field. J Integr Agric., 2015, 14: 106-113.

6. European Food Safety Authority (EFSA). Conclusion regarding the peer review of the pesticide risk assessment of the active substance ethephon. EFSA Scientific Report, 2008; 174: 1-65.

7. Gao B, Zhou YD, Li DM, Wang KC, Li M, Effect of ethephon on growth and yield of high-yield spring maize. J Northeast Agric Univ., 2009; 40: 13-21.

8. Goldental-Cohen S, Burstein C, Biton I, Ben Sasson S, Sadeh A, Many Y, Doron-Faigenboim A, Zemach H, Mugira Y, Schneider D, Birger R, Meir S, Philosoph-Hadas S, Irihomovitch V, Lavee S, Avidan B, Ben-Ari G, Ethephon induced oxidative stress in the olive leaf abscission zone enables development of a selective abscission compound. $B M C$ Plant Biol., 2017; 17(1): 87.

9. Hagemann HM, Winterhagen P, Hegele P Wünsche JN, Ethephon induced abscission in mango: physiological fruitlet responses. Front Plant Sci., 2015; 6: 706-711.

10. Hodjat M, Baeeri M, Rezvanfar MA, Rahimifard M, Gholami M, Abdollahi M, On the mechanism of genotoxicity of ethephon on embryonic fibroblast cells. Toxicol Mech Meth., 2017; 27: 173-180.

11. Hozyen HF, Eldebaky HA, Soror AH, Desouky HM, Shalaby SIA, Protective role of selenium against adverse effects of atrazine toxicity in male rats: biochemical, histopathological and molecular changes. Global Veterinaria, 2015; 15: 357-365.
12. Joint FAO/WHO meeting on pesticide residues (JMPR). Pesticide Residues in food 2002. Joint FAO/WHO meeting on Pesticide Residues. Ethephon. 2002. www.inchem. org.

13. Joint FAO/WHO meeting on pesticide residues (JMPR). Pesticide Residues in food 2016. Joint FAO/WHO meeting on pesticide residues. Ethephon. 2016. www.fao.org.

14. Mahajan BVC, Kaur T, Gill MIS, Studies on optimization of ripening techniques for banana. $J$ Food Sci Technol., 2010; 47: 315-319.

15. Montgomery JH, Agrochemicals Desk Reference: Environmental Data. Lewis Publishers, Chelsea, 1993.

16. Navarro-Alarcon M, Cabrera-Vique C, Selenium in food and the human body: a review. Sci Tot Environ., 2008; 400: 115-141.

17. Nurulain SM, Shafiullah M, Teratogenicity and embryotoxicity of organophosphorus compounds in animal models - a short review. Mill Med Sci Lett., 2012; 81: 16-26.

18. Pierik R, Tholen D, Poorter H, The janus face of ethylene: growth inhibition and stimulation. Trends Plant Sci., 2006; 11: 176-183.

19. Rayman MP, The importance of selenium to human health. The Lancet, 2000; 356: 233-241.

20. Report of the joint meeting of the FAO panel of experts on pesticide residues in food and the environment and the WHO core assessment group on pesticide residues, Geneva, Switzerland, 15-24 September 2015. FAO plant production and protection paper, 2015; 223: 131-155.

21. Tăşchină M, Copolovici DM, Bungău S, Lupitu AI, Copolovici L, Iovan C, The influence of residual acetaminophen on Phaseolus vulgaris L. secondary metabolites. Farmacia, 2017; 65(5): 709-713.

22. Teodor V, Cuciureanu M, Filip C, Zamoşteanu N, Cuciureanu R, Protective effects of selenium on acrylamide toxicity in the liver of the rat. Effects on the oxidative stress. Rev Med Chir Soc Med Nat Iaşi, 2011; 115: 612-618.

23. Yazar S, Baydan E, The subchronic toxic effects of plant growth promoters in mice. Ankara Univ Vet Fak Derg., 2008; 55: 17-21. 